\title{
Effect of Low Poly Tunnel and Planting time on Growth Parameters and Yield of Muskmelon
}

\author{
Ashish Ranjan ${ }^{\text {* }}$, Anand Kumar ${ }^{2}$, Suraj Prakash ${ }^{1}$ and Awadhesh Kumar Pal ${ }^{1}$ \\ ${ }^{1}$ Department of Horticulture, Bhola Paswan Shastri., Agricultural college, Purnea, India \\ ${ }^{2}$ Department of Plant Breeding and Genetics, Bihar Agricultural University, Sabour \\ (Bhagalpur), India \\ *Corresponding author
}

\begin{tabular}{|l|}
\hline Ke y w o r d s \\
$\begin{array}{l}\text { Musk melon, Poly } \\
\text { tunnel, Planting } \\
\text { time, Growth } \\
\text { parameters and } \\
\text { yield }\end{array}$ \\
\hline Article Info \\
\hline $\begin{array}{l}\text { Accepted: } \\
\text { 17 December } 2018 \\
\text { Available Online: } \\
\text { 10 January } 2019\end{array}$ \\
\hline
\end{tabular}

\section{Introduction}

Profitability of vegetable especially muskmelon production in Bihar is limited by a short season. Therefore, most growers' plant and harvest at the same time, which drives prices down (sometimes below breakeven point) negatively affecting income. The goal of this study was to investigate poly tunnel technology as a means to improve 
profitability of fresh market vegetables in Bihar. Poly tunnels allow growers to start planting earlier, so they can harvest earlier, and receive a higher price for their produce before vegetable prices begin to decline in mid-season. Poly tunnels benefits in musk melon cultivation including: frost protection, earliness in planting and harvesting, and season extension. This study is based on the impact of poly tunnel and planting time on the growth parameters and yield performance of Muskmelon. An analysis was also conducted to determine the economic benefit of each system tested. The outcome will be greater awareness among growers of the potential to use low tunnel technologies to reduce frost risks, and enhance earliness and profitability. The low tunnels had limited effect on total marketable fruit yields. However, since market prices were high at the beginning of the seasons the low tunnel treatments had the highest net revenue.

\section{Materials and Methods}

The present experiment was conducted at vegetable research farm, College of Horticulture, Noorsarai, Bihar Agricultural University, Sabour (Bhagalpur), Bihar during two years (2016-17 to 2017-18). The experiment was conducted in randomized block design in three replications with five treatments. The treatments consisted of five date of sowing i.e., $5^{\text {th }}$ December, $15^{\text {th }}$ December, $25^{\text {th }}$ December, $5^{\text {th }}$ January and $15^{\text {th }}$ January under open field as well as low plastic poly tunnel respectively. The farmer practice is taken as a control in open field. Seedling of muskmelon var. Madhuraja was planted with spacing of $1.5 \mathrm{~m} \times 30 \mathrm{~cm}$. For making plastic low tunnel, $60 \mathrm{~cm}$ width, 50 $\mathrm{cm}$ high and 50 micron transparent plastic were used, immature bamboo stick were pegged on the both sides of water channel. The tunnels were made in north south direction and vents were made in tunnel on east side. The five plants were randomly selected in each treatment for recording various plant growth parameters and yield parameters. Mean values of different characters were used for statistical analysis. The data were recorded on vine length $(\mathrm{cm})$, number of branches, vine length, number of leafs per plant, number of fruits per plant, fruit diameter, average fruit weight, fruit yield per plant, average fruit weight and T.S.S. Mostly artificial soil media was used for raising healthy and vigorous seedlings of vegetable in plastic pro- trays. There were three ingredients viz., cocopeat, vermiculite and perlite which are being used as a rooting medium for raising the nursery. Benefit of this nursery was better root development of transplants and reduction in the mortality in transplanting of seedling as compared to the traditional system of nursery raising. Seedlings were raised by sowing seeds in plastic pro-trays which were filled with growing media prepared by mixing coco. The treatments consisted of different date of sowing i.e., $5^{\text {th }}$ December, $15^{\text {th }}$ December, $25^{\text {th }}$ December, $5^{\text {th }}$ January and $15^{\text {th }}$ January in poly tunnel, Un protected open field and farmers practice. In treatment T1 to T5 plants were protected with the help of plastic sheet but small holes were made with the help of needle in the plastic sheet. All the cultural practices were done as per package of practices for open cultivation. Data was recorded on number of fruits per plant, fruit weight $(\mathrm{g})$, yield/plant $(\mathrm{g})$, average fruit weight $(\mathrm{g})$ and total fruit yield $(\mathrm{q} / \mathrm{ha})$.

\section{Results and Discussion}

The analysis of pooled data for two years (Table-1) revealed that revealed that number of fruits per plant, fruit weight, yield per plant and yield per hectare, were significantly influenced by the growing environment conditions and planting time. Maximum number of fruits per plant, yield per plant and 
yield per hectare were found when the planting was done on $\mathrm{S}_{2}=15^{\text {th }}$ December under low tunnel followed by $S_{5}=15$ th January over other date of sowing under low tunnel. Fruit weight was recorded in $S_{5}=15$ th January followed by $S 4=5^{\text {th }}$ January under low tunnel whereas under open field condition, it was noticed maximum in condition on $15^{\text {th }}$ December date of planting. Low tunnels modify microclimate by raising soil and air temperatures. In general, low tunnels allow shortwave solar radiation to pass through during the day and the plastic material slows long wave radiation from the surface at night (Snyder and Melo-Abreu, 2005). The heat that is absorbed could not easily be passed down into the soil because of the insulation of the air between the low tunnel, plastic mulch, and the soils surface. The interior microclimate is further modified as the tunnel material slows convective mixing over the covered surface, reducing both sensible and latent energy losses from the surface (any condensation that does occur on the plastic will release latent heat and warm the plastic) and increasing the ground heat flux.

Table.1 Effect of planting time and growing conditions on growth and yield attributing parameters of Muskmelon

\begin{tabular}{|c|c|c|c|c|}
\hline Treatments & $\begin{array}{l}\text { No. of } \\
\text { fruits per } \\
\text { plant }\end{array}$ & $\begin{array}{c}\text { Average Fruit } \\
\text { wt (g) }\end{array}$ & $\begin{array}{l}\text { Fruit yield per } \\
\text { plant (Kg) }\end{array}$ & Yield (q/ha) \\
\hline $\begin{array}{c}\text { Low Poly tunnel S1 }=5^{\text {th }} \\
\text { December }\end{array}$ & 13.26 & 482.70 & 06.40 & 1066.62 \\
\hline $\begin{array}{c}\text { Low Poly tunnel } S 2=15^{\text {th }} \\
\text { December }\end{array}$ & 18.36 & 494.06 & 09.07 & 1511.60 \\
\hline $\mathrm{S3}=25^{\text {th }}$ December & 13.20 & 504.40 & 06.65 & 1108.28 \\
\hline $\begin{array}{c}\text { Low Poly tunnel S4 }=5^{\text {th }} \\
\text { January }\end{array}$ & 15.26 & 505.37 & 07.71 & 1284.94 \\
\hline $\begin{array}{c}\text { Low Poly tunnel S5 }=15^{\text {th }} \\
\text { January }\end{array}$ & 16.00 & 523.66 & 08.37 & 1394.94 \\
\hline $\begin{array}{c}\text { Open field condition } S 1= \\
5^{\text {th }} \text { December }\end{array}$ & 06.00 & 226.33 & 01.35 & 0224.99 \\
\hline $\begin{array}{c}\text { Open field condition S2 }= \\
15^{\text {th }} \text { December }\end{array}$ & 09.33 & 448.00 & 04.17 & 0694.97 \\
\hline $\begin{array}{c}\text { Open field condition } \mathrm{S3}= \\
25^{\text {th }} \text { December }\end{array}$ & 05.13 & 375.06 & 01.92 & 0319.98 \\
\hline $\begin{array}{c}\text { Open field condition S4= } \\
5^{\text {th }} \text { January }\end{array}$ & 09.43 & 256.20 & 02.41 & 0401.65 \\
\hline $\begin{array}{c}\text { Open field condition S5= } \\
15^{\text {th }} \text { January }\end{array}$ & 11.00 & 260.50 & 02.86 & 0476.64 \\
\hline $\begin{array}{c}\text { Farmers practice S6= } \\
15^{\text {th }} \text { February }\end{array}$ & 19.36 & 547.00 & 10.58 & 1763.26 \\
\hline $\operatorname{SEm}(+-)$ & 1.38 & 39.02 & 0.73 & 48.0 \\
\hline CD at $5 \%$ & 4.4 & 123.0 & 2.3 & 223 \\
\hline
\end{tabular}


Table.2 (Contd.) Effect of planting time and growing conditions on growth and yield attributing parameters of Muskmelon

\begin{tabular}{|c|c|c|c|c|}
\hline Treatments & $\begin{array}{c}\text { No. of Leafs per } \\
\text { plant }\end{array}$ & Vine length $(\mathrm{cm})$ & $\begin{array}{l}\text { Fruit diameter } \\
\qquad(\mathbf{m m})\end{array}$ & T.S.S \\
\hline $\begin{array}{c}\text { Low Poly tunnel S1 }=5^{\text {th }} \\
\text { December }\end{array}$ & 88.00 & 98.00 & 88.67 & 8.20 \\
\hline $\begin{array}{c}\text { Low Poly tunnel S2 }=15^{\text {th }} \\
\text { December }\end{array}$ & 144.08 & 159.24 & 98.37 & 9.87 \\
\hline S3 $=25^{\text {th }}$ December & 119.33 & 119.33 & 97.78 & 10.19 \\
\hline Low Poly tunnel $\mathbf{S} 4=5^{\text {th }}$ January & 152.00 & 152.33 & 99.96 & 10.62 \\
\hline Low Poly tunnel S5 $=15^{\text {th }}$ January & 148.33 & 148.33 & 98.13 & 10.93 \\
\hline $\begin{array}{l}\text { Open field condition } \mathrm{S} 1=5^{\text {th }} \\
\text { December }\end{array}$ & 84.00 & 111.66 & 80.26 & 9.92 \\
\hline $\begin{array}{c}\text { Open field condition } S 2=15^{\text {th }} \\
\text { December }\end{array}$ & 119.33 & 122.33 & 84.91 & 10.17 \\
\hline $\begin{array}{c}\text { Open field condition } \mathrm{S3}=25^{\text {th }} \\
\text { December }\end{array}$ & 109.33 & 109.33 & 93.26 & 10.43 \\
\hline $\begin{array}{l}\text { Open field condition } \mathrm{S} 4=\mathbf{5}^{\text {th }} \\
\text { January }\end{array}$ & 121.00 & 120.33 & 78.94 & 9.15 \\
\hline $\begin{array}{c}\text { Open field condition S5 }=15^{\text {th }} \\
\text { January }\end{array}$ & 148.33 & 185.00 & 95.52 & 10.10 \\
\hline $\begin{array}{c}\text { Farmers practice } \mathrm{S} 6= \\
15^{\text {th }} \text { February }\end{array}$ & 151.66 & 185.00 & 105.71 & 10.89 \\
\hline S.E. (+-) & 8.18 & 9.70 & 3.55 & 0.17 \\
\hline CD at $5 \%$ & 25.8 & 30.6 & 11.2 & 0.6 \\
\hline
\end{tabular}

The present investigation also revealed that total fruit yield was significantly higher in low tunnel than open field condition and almost double than the open field crop. Buczkowska et al., (1994) revealed that total yield under low tunnel was higher than under open conditions. Sari et al., (1994) reported that increase in yield under low tunnel was due to increase in harvesting span in cucumber. Fruit number per plant was recorded more under protected conditions and it was significantly higher than open field crop. This is due to the fact that muskmelon grown under plastic tunnel got favourable conditions for maximum growth, flowering and fruiting in comparison to other treatments resulting in more number of fruits per plant. Kacjan and Osvald (1997) obtained more fruits per plant under plastic tunnel in pepper. They attributed it to the increase in temperature in tunnel during the cold which results in more growth and yield of the crop. The average fruit weight under low tunnel was also significantly higher than other treatments. It was also observed that average fruit weight in first two picking was significantly higher in low tunnel than the unprotected. Macua et al., (1999) reported in tomato that by use of plastic covers the crop get early and prolong for longer duration than the normal grown crop. The results obtained during the two year study clearly indicated that the technology will help the growers to raise the muskmelon in early summer and increase the harvesting span of the crop fetching higher price. The other yield contributing traits like number of leafs per plant was noticed maximum in $\mathrm{S} 4=15$ th January followed by $\mathrm{S} 5=15$ th January under low tunnel condition followed by S5= 15 January under open system. Vine length was recorded maximum in $\mathrm{S} 2=15^{\text {th }}$ December under low tunnel condition followed by S5= $15^{\text {th }}$ January in open system. Fruit diameter and T.S.S. recorded maximum in $\mathrm{S} 4=5^{\text {th }}$ January in 
low tunnel followed by $S 6=15^{\text {th }}$ February in framer practice.

Maximum yield in muskmelon was recorded in $\mathrm{S}_{2}$, it might be due to better growth and development of all yield contributing parameters of muskmelon under low tunnel which were due to increases the net photosynthesis and production of more assimilates available for individual to grow. Similar results were also given by Singh el al (1989). Vegetative growth was greatest in plants in the tunnel where the thermal condition were best early and total marketable yield were highest under the poly tunnel (Siwek and Capecka 1999). It is important to note that no significant differences were observed in fruit weight in both condition i.e., grown in tunnels and in open field. Net income and cost benefit ratio is significantly influenced by off season flowering and fruiting induced by low tunnel technology. Net income and cost benefit ratio was found maximum when sowing the crop on 15th December under low poly tunnel. This might be due to high market value in offseason. Growers typically reported satisfaction with adopting this technology. Poly tunnels allow muskmelon growers to start planting earlier, so they can harvest earlier, and receive a higher price for their produce before vegetable prices begin to decline in mid-season.

\section{References}

Buczkowska, H., Babik, I. and Rumpel, J. (1994). Usefulness of a slidable tunnel in accelerated vegetable growing. Seventh International symposium on timing field production of vegetables. Acta Hort., 371: 297-304.

Cheema, D.S., Kaur, P. and Kaur, S. (2004).
Offseason cultivation under net house conditions. Acta Hort., 659: 177-81.

Kacjan Marsin, N. and Osvald, J. (1997). The influence of different cover materials of greenhouses on growth and development of pepper (Capsicum annuum L.). Zbornic BiotehniskeFakultete-Univerze-v-Ljubljani,Kmetijstvo, 69: 141-46.

Immirzi, B; Malinconico, M; Casale, E., Mormile, P., Shenker, Y. and BenYehoshua, S. (1998). Testing of innovative co-extruded films in anticipated cultures in South Italy. $14^{\text {th }}$ International Congress on Plastics in Agriculture. Tel Aviv, Israel, March 1997-1998, pp. 177-80.

Macua, H; Santos, A. and Zuniga, J. (1999). The effect of the planting date on the programmation of yield and quality of processing tomato in Navarre (Spain). Acta Hort., 487: 229-32.Pakyurek, A.Y., Abak, K., Sari, N., Guler, H. Y., Cockshull, K.E., Tuzel, Y. and Gul, A. (1994). Influence of mulching on earliness and yield of some vegetables grown under high tunnels. Second symposium on protected cultivation of solanacea in mild winter climates, Adana, Turkey, 13-16 April 1993. Acta Hort., 366: 155-160.

Sari, N., Guler, H.Y., Abak, K., Pakyurek, Y., Babik, I. and Rumpel, J. (1994). Effect of mulch and tunnel on the yield and harvesting period of cucumber and squash. Seventh International symposium on timing field production of vegetables, Skierniewice, Poland, 2327 August 1993. Acta Hort., 371: 305310.

\section{How to cite this article:}

AshishRanjan, Anand Kumar, Suraj Prakash and Awadhesh Kumar Pal. 2019. Effect of Low Poly Tunnel and Planting time on Growth Parameters and Yield of Muskmelon. Int.J.Curr.Microbiol.App.Sci. 8(01): 2735-2739. doi: https://doi.org/10.20546/ijcmas.2019.801.289 